\title{
AC 2008-421: ENSURING A STRONG U.S. ENGINEERING WORKFORCE FOR TECHNOLOGY INNOVATION COMPETITIVENESS: ECONOMIC IMPACT OF THE PARTNERSHIP FOR THE NATION
}

Norman Egbert, Rolls-Royce Corporation

Norman F. Egbert is vice president of engineering and technolgy, Rolls-Royce Corporation.

\section{Donald Keating, University of South Carolina}

Donald A. Keating is professor emeritus of mechanical engineering, University of South Carolina, and chair of the National Collaborative Task Force.

Eugene DeLoatch, Morgan State University 


\title{
Ensuring a Strong U.S. Engineering Workforce for Innovation: Impact of Advancing Professional Engineering Graduate Education for U.S. Competitiveness and National Security
}

\begin{abstract}
Engineering is a creative profession, concerned with the combining of human, material, and economic resources to meet the needs of society ... for the advancement and betterment of human welfare.
\end{abstract}

National Collaborative Task Force on Engineering Graduate Education Reform - 2008

\section{Introduction}

This is the fourth of four invited papers prepared for the special panel session of the National Collaborative Task Force on Engineering Graduate Education Reform. This paper cites the need for reform, the vision for change, and enumerates the immediate impact, significance, and longrange returns to be gained from this unique national initiative between academia and industry to deliberately advance professional graduate engineering education that further strengthens the 'creative, innovative, and leadership' capacity of the U.S. Engineering Workforce in America's industry for enhanced U.S. competitiveness and national security purposes.

\section{Engineering and the Nation's Future}

As the National Academy of Engineering has pointed out, the modern practice of engineering is 'a profoundly creative process ... the outcome, of which, is new technology.' 1,2,3 As such, our nation's economic competitiveness and national security depends largely upon nurturing continuous engineering progress and innovation as an essential ingredient in America's industry, which depends in turn upon nurturing the further professional growth and graduate development of the nation's engineers in industry who bring this progress about in the global arena.

\subsection{The Imperative - Engineering Progress and Innovation in America's Industry is Essential for U.S. Competitiveness and National Security}

New products, new processes, new industries, and the creation of new jobs require a continuous flow of new 'ideas and concepts' that evolve from the engineering practitioner's professional approach to creative problem-solving and deliberate application of the engineering method to bring about effective solutions responsive to real-world needs and meaningful problems. Similarly, our national security against aggression demands the generation and advanced development of new / improved / breakthrough technology through creative engineering practice that outpaces and counters potential threats. Without responsible engineering leadership and professional engineering education that nurtures continuous engineering progress in America's industry, 'no amount of achievement in other areas can ensure our economic prosperity and national security in the modern world.' 


\subsection{The Modern Paradigm of the Practice of Engineering - Learning, Creativity, and Engagement in Practice for Purposeful Innovation}

However, to compete more effectively in the innovation-driven economy, we must also revitalize America's universities to better meet the graduate professional needs of the U.S. engineering profession in the nation's industry.

As the National Academy's Committee on Science, Engineering, and Public Policy (COSEPUP) report [Reshaping the Graduate Education of Scientists and Engineers] ${ }^{4}$ pointed out in 1995, science and engineering graduate education has evolved during the last four decades in the United States primarily as research-oriented, largely as an outgrowth of 1945 U.S. science policy for basic research. ${ }^{5}$

But, key to improving the professional educational process in engineering for innovation is the realization that the modern practice of engineering for technology development \& innovation 'has itself changed substantially' from that portrayed by linear research-driven paradigm of engineering practice of 1945 U.S. science policy (See Appendix A). ${ }^{6}$ Yet, with notable exceptions, the mainstream of U.S. engineering graduate education has not reflected this change.

As outcomes of investigating the need for reform of engineering graduate education for competitiveness in the UK and in the US, the UK Parnaby Committee and the US National Collaborative Task Force have basically reached similar conclusions from essentially two parallel efforts and from two different national perspectives:

- UK Parnaby Report

Although the UK government had already begun to successfully implement new professionally-oriented engineering graduate education programs at the Masters of Engineering skills level throughout the country - through the Teaching Company Scheme (TCS) to stimulate nation-wide innovation - the UK government also tasked John Parnaby (Lucas Industries) to set up a committee to also consider improvement in engineering graduate education at higher levels to improve UK prosperity and competitiveness. ${ }^{7,8}$ The recommendation of this committee was that professional Doctor of Engineering (EngD) programs should be instituted in the UK by government as follow-on to the successful Masters programs developed in partnership between industry and universities.

In its summary of recommendations, the Parnaby Report states -

"The major conclusion of the Working Party is that there is a need for a major new scheme providing engineering doctorate programmes in the processes and practice of engineering required by industry ... Such an engineering doctorate would be distinct from, and complementary to, the traditional existing $\mathrm{PhD}$, which has been criticized for its lack of industrial relevance" ... and ... "too narrow and academic for industry's needs."

"The evidence collected overseas and from the Total Technology programme in the UK, indicates that these sectors of industry would benefit from a more industrially oriented engineering doctorate. Indeed we believe that the whole of the engineering industry in the UK would benefit greatly from the introduction of such a doctorate." 
- US National Collaborative Task Force

-

During its investigations for engineering educational improvement, the US National Collaborative Task Force also concludes that a new, but distinctive American approach is needed for the post-baccalaureate professional education of engineers and engineering leaders in the United States that supports the American model that the majority of US engineers who are pursuing professional careers do not remain at the universities but enter engineering practice in industry or government service immediately upon graduation.

While excellent for its intended purpose of 'scientific discovery', investigation, and 'inquiry', the National Collaborative Task Force concludes that traditional researchoriented M.S. and Ph.D. graduate education does not meet the full professional spectrum of educational needs or reflect the 'engineering method' of creative engineering practice for the majority of the nation's engineers, who are not pursuing research-careers of scientific investigation and inquiry, but rather who, as working professionals, are pursuing the creative practice of engineering in industry for technology-development and innovation.

For these engineers, a different approach and educational method is needed, which better supports lifelong learning and the modern paradigm of the practice of engineering for creative technology development \& innovation. As the 1974 National Science Foundation report [Workshop on Continuing Education for Engineers at Mid-Career] pointed out "Coursework has not been designed which correlates well with the professional growth of engineers, either as technical specialists or as managers ... Selection of educational experiences generally relies on the individual engineer's selection from a 'cafeteria' of study opportunities." 9

\subsection{The Technology Context of Engineering - Educating the Engineer as a Professional and Leader for Innovation}

Subsequently, the National Collaborative Task Force concludes that the system of U.S. engineering graduate education must be reshaped to reflect the fundamental paradigm shift in professional engineering practice and include a complementary professional engineering component, that promotes 'lifelong learning' and professional growth throughout the engineer's entire professional career in creative engineering practice in industry - if we are, as a nation, to develop our nation's domestic, creative engineering talent in industry to their fullest 'creative, innovative, and leadership' potentials for the creative practice of engineering.

As the National Academy of Engineering has pointed out, the context of engineering practice is viewed today in a technological context as 'design under constraint' for purposeful 'creative problem-solving' that is needs-driven, encompassing all phases of problem recognition, formulation, and solution. In its broadest sense, the essence of creative engineering practice encompasses the functions of needs-recognition, vision, conceptual planning and creative design for the generation and development of new technology and executive engineering leadership roles of organization and responsible leadership to bring new, improved, and breakthrough 'ideas and concepts' to practical use in the creative solution of the hopes, wants, and needs of people 
for the advancement and improvement of the quality of life (both domestic and internationally) for the future.

In recent years, many of our premier engineering oriented companies have described their core expertise as systems engineering and/or the delivery of systems. It is in this context of system engineering that creative engineering practice by the U.S. engineering community has set itself

apart. The U.S. Engineering community has delivered products with amazing new functionality that satisfy customer needs and desires, and that until recently would have been deemed impossible. This has been accomplished by visionary technical leaders who have described big picture challenges. These same leaders have provided a risk taking friendly environment where diverse multi disciplinary teams have had the freedom to explore new domain spaces to create the breakthrough concepts. It is the arena that the U.S. must build a critical mass of higher skilled engineering practitioners across the career spectrum of the workforce to ensure we maintain the technical preeminence that has enabled our current physical and economic security. Now is the time to martial the forces of Academia and industry to produce the engineering leadership talent pipeline via a marriage of advanced education and hands on engineering practice.

\subsection{Revitalizing the U.S. Engineering Workforce for Innovation in Industry}

Today, U.S. engineering development plays a pivotal role in sustaining our competitive edge in the innovation-driven, global economy. As Porter has pointed out - "NATIONAL PROSPERITY IS CREATED, not inherited. It does not grow out of a country's natural endowments, its labor pool, its interest rates or its currency's value, as classical economics insists. A nation's competitiveness depends on the capacity of its industry to innovate and upgrade" ... and ... "Prosperity for both companies and countries depends on the nature of the local environment in which competition takes place." 10

Without denigrating the importance of basic research for scientific discovery and investigation, the nation's ability to deliver highest value added system engineering via generation of effective technological innovation for U.S. economic competitiveness and national security depends in large measure upon the capacity of the U.S. Engineering Workforce. That workforce must increase its systems engineering skills to 'create, innovate, and lead' through creative engineering practice in America's industry. As Fred Gary, corporate vice president of engineering at General Electric Co., pointed out to ASEE, years ago, development [not research] is what most engineers do in creating and improving new products, processes, systems, and operations in industry. ${ }^{11}$

Accordingly, the U.S. Engineering Workforce in industry is one of the nation's most vital, creative assets in sustaining our economic development, national security, improvement in the quality of life, and well-being as a nation. As the Council on Competitiveness points out - "The Council's business leaders agree that every company's most important asset are the people who walk in its doors every morning ... Talented people creating new ideas and innovative technologies keep the economy strong, and growing stronger ... The education and training that spark Americans' creativity and give them cutting-edge skills are a key to competitiveness." 12,13 
Accordingly, America's competitive edge in leading the world in engineering and technological innovation depends in turn upon the U.S. system of engineering graduate education to support the lifelong graduate development of our creative engineering talent for innovation.

Subsequently, the further professional graduate education of our industry's creative engineering talent is no longer considered a fringe benefit. Top engineering executives now understand that the need to recruit, to further develop, and to retain the company's creative engineering base is a sound financial investment to sustain the company's innovative capacity and competitive edge.

\subsection{Professional Graduate Education of the Engineer for Creative Practice - Integrating Advanced Professional Studies with Experience and Practice for Innovation}

To meet this challenge, the ASEE-National Collaborative Task Force on Engineering Graduate Education Reform is embarking on a very bold initiative to advance professionally-oriented, practice-based engineering graduate education in the national interest to enhance U.S. economic competitiveness and our national security. Toward this aim, the National Collaborative Task Force initiative reaffirms, what previous engineering reports have stated before that: Engineering - as a creative profession - is and must remain one of the nation's most valued professions for creating new solutions, improvements and technological innovations that benefit society.

The National Collaborative concludes also that the education of the engineer is not simply a onetime event of 4, 5, or 8 year duration. As the ASEE-Green Report [Engineering Education for a Changing World] has pointed out, an engineer's education is a lifelong learning and growth process. ${ }^{14}$ To make the opportunity for 'lifelong learning' a reality, the National Collaborative Task Force believes that professional graduate education of engineers, through the advanced level, capable of distinguishing system engineering must be integrative with and enable positive growth of the engineer for the practice of engineering throughout the engineer's entire professional career of creative practice.

Whereas undergraduate engineering education prepares the young engineering graduate for entry-level work, it is just the beginning of an engineer's further professional development for creative work of increasing responsibility. The advanced professional education of the engineer is much more than class room instruction. The National Collaborative concludes that the actual process of generating, designing, developing, and innovating new / improved / breakthrough technology is, itself, one of 'learning by doing' and that of 'intrinsic creative development' by doing as a reflective creative practitioner.

The National Collaborative concludes also that the practice of engineering is itself both a creative process and a learning process that goes far beyond the conventional wisdom of the transmission and acquisition of knowledge from teacher to student. At this level of advanced practice, the engineer is a reflective, creative professional whose work generates new and improved 'ideas' and 'concepts' resulting in the purposeful development of technology, which ultimately results in the creation of new technical knowledge in his or her field.

As Kingston notes, "a prototype should always be regarded as a learning device, never merely as a proof of design." 15 And the vital key to successful technological innovation is effective 
engineering leadership and the 'product champion'. As Kingston notes - "The importance of the "champion" is seen through the effect of his or her leadership on the learning process." Also important to engineering workforce development for meaningful creative work, for both the company and the engineer, is the experience factor and retention factor in developing a company's engineer [although too often overlooked and undervalued].

As the Department of Defense study, Project Hindsight, has pointed out - "In examining the personal histories of engineers who had contributed most heavily to the new technology of use to the Department, the employment stability of these individuals stood out as a most significant factor. Moreover, it was found that the most effective engineer - in terms of the probability that he or she will come up with something that will be profitable to the organization is one who has been in the company for a number of years. The modal point on the distribution curve displaying length of employment against probability of making a useful contribution occurs at between seven and nine years of employment. Clearly, if the professional turn-over rate exceeds $10 \%$ to $15 \%$ per year, it will be most unlikely that the peak performance of the laboratory will ever be achieved [Cetron]." 15, 16

Of the 70,000 new engineering graduates [2006 ASEE-Statistics] who graduate each year from the nation's undergraduate engineering programs, and who enter the resource of practitioners within the U.S. engineering Workforce (See Appendix B), most enter industry or government service immediately upon graduation; are the nation's emerging creative talent who have undergone rigorous learning experiences in the basic fundamentals and rudiments of engineering practice; and are the nation's future engineering leaders pursuing responsible positions in engineering practice in industry for technology development \& innovation. However, whereas undergraduate engineering education adequately prepares the engineering graduate for entrance into the practicing profession of engineering [ABET], it does not prepare the graduate engineer for practice and leadership at all levels of engineering.

It is now recognized that there are nine progressive levels of further growth and progressive responsibility beyond beginning entry-level engineering education that require further professional graduate development combined with progressive experience in engineering practice in order for the engineer to reach his or her fullest potential for meaningful creative engineering works. ${ }^{18,19}$ These nine stages of further professional growth and progressive experience in the practice of engineering encompass:

A) Early-career engineering skill-sets focusing on technology innovation at the more fundamental levels and responsible engineering leadership at beginning to advanced project engineering levels

Levels I - IV Engineering

B) Mid-career engineering skill-sets focusing on technology innovation and responsible engineering leadership at technical program delivery levels

Levels IV - VI Engineering

C) Senior-career engineering skill-sets focusing on systems technological engineering, innovation and responsible, visionary engineering leadership at corporate policy levels 


\section{Levels VI - IX Engineering}

As such the question becomes:

\section{- Question}

Do we as a nation want to provide opportunity that continues the further professional growth and graduate development of our nation's creative engineering workforce talent to attain their fullest 'creative, innovative, and leadership' potential in industry - which is the nation's primary creative resource for delivery of systems, technology development $\&$ innovation for U.S. competitiveness and national security?

\section{- Answer}

The answer, obviously, must be yes, if we - as a nation - want to compete and unleash the 'creative talent' of the U.S. engineering workforce in industry for innovation.

\section{The Central Premise - Investing in the Professional Graduate Development of the U.S. Engineering Workforce for Innovation in Industry}

Based on the national importance of the U.S. engineering workforce to the nation's industry and to the nation's future for economic competitiveness and national security, the ASEE-National Collaborative initiative is building upon Whitfield's central premise that - "It is taken as selfevident that the creative output of engineering will be raised quickest and over the widest area by successful efforts to improve the creativity of the engineer already in industry, specifically the engineer who has added an adequacy of experience to his or her basic technical training."

\subsection{The Investment - Creating Regional Clusters of Advanced Professional Graduate Engineering Education for Innovation across the United States}

Toward this aim, the ASEE-National Collaborative Task Force on Engineering Graduate Education Reform is embarking on a deliberate, planned advancement in U.S. engineering graduate education with the specific objects:

- To define, align, develop, and implement a coherent sequence of professional engineering graduate education and educational process - integrative with engineering and systems engineering practice - that matches and supports the modern paradigm of the practice of engineering and the nine stages of further growth, attributes, and increasing responsibilities of engineering practice, beyond the engineer's basic undergraduate education of pre-professional learning, that is more responsive to all progressive levels of engineering leadership responsibility and the process of engineering for needs-driven, creative technology development $\&$ innovation

- To foster the further advanced professional graduate education of the nation's engineers for lifelong learning, at all leadership levels of engineering leadership, throughout the engineer's entire creative career in America's industry or government service; and thereby to concurrently stimulate the continuous generation, development, and innovation 
of new / improved / breakthrough technology in industry for the advancement and betterment of society, economic development, or national security purposes.

- To create accessible opportunity for further advanced professional education for the nation's engineers by creating regional clusters of advanced professional engineering graduate education for innovation throughout regional engineering communities across the nation; thereby strengthening the U.S. professional engineering education infrastructure for development of the U.S. engineering workforce for enhanced competitiveness and national security.

However, this initiative will not occur by itself or happen overnight on the majority of university campuses. The initiative will require sound financial investment by the federal government, state governments, industry, and universities in kind to bring this needed change about. As the necessary catalyst for change, the National Collaborative Task Force is providing the overall systems direction and leadership role, in strong alliance with industry and participating universities, all working together toward a common shared goal to bring this much needed educational advancement about in the national interest.

\subsection{Vision - Innovative Graduate Centers of Advanced Studies for Engineering Leadership, Technology Innovation \& Policy}

Investing in the deliberate advancement of practice-centered, professional graduate education for the U.S. Engineering Workforce is an investment in 'human capacity building for technology innovation' that will have multiplying effects in building our nation's innovative capacity for generating new / improved / breakthrough technology in industry and developing our engineers as champions and leaders that is at the very heart of enhancing U.S. economic competitiveness.

In the spirit of America's previous 'land-grant' investment in higher education that originated the basic foundation's of U.S. professionally-oriented education for practical engineering purposes, the National Collaborative proposes to implement, develop, continuously improve, and replicate this educational advancement through the purposeful establishment of 10 innovative graduate centers, as a pilot national demonstration project, in 10 initial start-up states across the nation.

These practice-centered, interdisciplinary graduate centers for professional engineering graduate education for innovation and advanced practice will serve three primary functions. They include the following:

- Advanced Studies in Engineering Leadership, Technology Innovation and Policy. To serve as centers of high-quality professional engineering education by establishing, developing and implementing coherent programs of professionally-oriented, practicecentered engineering graduate education through the professional spectrum of M.Eng., Eng.D., and Fellow levels of advanced systems engineering practice for engineers and engineering leaders within their respective regional industries.

- Advanced Technology Development Laboratory for Innovation [Invention Factory]. To serve as working environment that fosters professional creative scholarship in the practice of engineering for innovation by establishing, developing, and implementing a 
'teaching - laboratory' for advanced engineering development that serves to develop the creative engineering scholarship of center faculty for faculty development and that of promising undergraduate engineering students during the summers.

Whereas NSF has successfully created and implemented Research Experiences for Undergraduates (REU) on university campuses across the nation, we can do in a similar manner to create and implement Technology Development Experiences for Undergraduates (TDEU) as a training ground and recruitment resource to sustain the nation's pipeline of 'creative engineering talent' for industry. This program will provide undergraduates the opportunity to conduct meaningful systems technology development $\&$ innovation under the guidance and mentorship of core 'center' faculty members and distinguished visiting faculty from regional industry.

- Distinguished Lecture Series in the Practice of Engineering and its Leadership. To serve as a platform for motivation, encouragement, and inspiration in the practice of engineering and systems engineering by establishing, developing, and implementing an annual distinguished lecture series that sustains the 'spirit and intent' of the graduate center in the advancement of the practice of engineering and its leadership in meaningful creative work though invited addresses by distinguished engineers from industry, government service, or private practice with sponsors, friends, faculty, and students of the center.

\section{National Significance / Impact / New Technology and 'Human Capital' Outcomes}

The creative returns from this investment and advancement in U.S. professional engineering graduate education to enhance our nation's innovative engineering capacity for enhanced U.S. competitiveness are far reaching and attainable across all states and regions of the nation.

\subsection{The Creative Returns from the Investment - Developing New Innovative Systems Technology and U.S. Engineering-Leaders in Industry}

The practical outcomes from this initiative extend to the further graduate development of our engineers as 'champions, innovators, and leaders' of new innovative systems and supporting technology and to the tangible outcomes of generating new innovative technology itself through the outcomes of project-based learning, at all levels of engineering, responsive to real-world needs of industry.

\subsection{Project-Based Professional Engineering Graduate Education \& Creative Practice - Needs Finding, Selection and Evaluation of Technology Development / Innovation Projects}

However, the ASEE-National Collaborative initiative is neither 'reinventing the wheel' in higher professional education nor is it exploring unknown educational concepts. But, many of these concepts have not been developed on the larger national scale. Rather, the ASEE-National Collaborative for Engineering Graduate Education Reform is building the initiative on the 'shoulders of giants' and work of previous leaders of ASEE from both industry and academia who recognized the need for advanced professional education in engineering practice years ago. 
The ASEE-National Collaborative Task Force is extending this previous work to the next level of excellence for the practicing profession of engineering. Of particular note, is the advancement of project-base learning for creative practice that Dean Solomon Hollister introduced into professional engineering education at Cornell University in the 1950's. This advancement has proven successful for over 50 years, as have many of the graduates of this then unique professional educational approach for creative engineering practice.

From an educational and financial analysis, the ASEE-National Collaborative initiative is both educationally sound, proven, adaptable to all regions of the nation, and is extremely costeffective. Feasibility analysis to date indicates that the National Collaborative's approach of integrating professional graduate engineering education with on-going creative engineering practice and project-based learning in industry will generate [median] technological returns of over 10 to 1 .

Systems level achievements and the enabling innovative technological outcomes do not occur by happenstance. Rather they are the expected outcomes created at the responsibility level of the experienced, practitioner / student through a planned, deliberate engineering process of development, attacking real-world problems of priority and interest to industry. In this process, the graduate practitioner / student engages in all phases of the engineering development process for planned innovation: from vision, needs recognition, understanding of the problem, conceptualization of new 'ideas' and 'concepts', advanced development, through multidiscipline implementation and innovation into new useful technology.

Based on 'shared best practice' within the National Collaborative at Purdue University and at the Rochester Institute of Technology, typical technology-development project outcomes indicate that for industry's moderate tuition investment of $\$ 20,000$ per practitioner / engineer-employee, that a returning savings or improvement of $\$ 100,000$ to $\$ 300,000$ per engineering project is reasonably expected. This return is regarded frequently as a technological improvement or innovation that keeps giving over the years.

Thus, an enrollment of 100 advanced practitioner-students, engaging in professional graduate education at each Graduate Center, would yield a multiplying innovation return of $\mathbf{\$ 2 0}$ million worth [100 x $\$ 200,000$ per project] of new innovative technology across statewide industry; contributing to economic development; creating new jobs; and growing each state's home-based industry at the cutting edge of technology.

\subsection{Enhancing Regional Technological Innovation across the United States - By Developing the U.S. Engineering Workforce for Innovation in Our Domestic Industry}

Enhancing the capacity for regional innovation, as the Council on Competitiveness has pointed out, is vitally important in strengthening America's prosperity and competitiveness as a nation. The initiative's action plan to found 10 new regional graduate centers across the country [and eventually in each state] provides a very cost-effective opportunity to further the advanced professional graduate engineering education of the nation's engineers within the regional engineering workforce for leadership of technology development $\&$ innovation, that will have significant and lasting impact over the long-term for accelerating the nation's engineering 
progress for U.S. competitiveness and our national security. The impact, benefits, and outcomes of the ASEE-National Collaborative initiative are multifaceted and yielding significant returns with multiplying effects that are far greater than the initial financial investment. These returns will yield immediate and long-term benefits to the nation, the states, universities, industry, and to the nation's engineers and the practicing profession as a whole (See Appendix D).

At a cost-effective engineering innovation return of \$20 million worth of new innovative technology generated per state per year, an initial start-up of 10 Graduate Centers as 'pilot programs' of advanced professional engineering graduate education for innovation in 10 states will generate over $\mathbf{\$ 2 0 0}$ million worth of new / improved / breakthrough technology per year with accumulating effects of increased statewide, regional innovation to accrue in each of these states across the country; and it will further develop over 1000 engineers and engineering leaders in our domestic industry each year.

From a cost-effective perspective, this educational workforce investment more than pays for itself by generating new innovative technology and by building our nation's 'human capacity' for statewide and regional engineering innovation across the country simultaneously. For all 50 states, this concept has the potential to create over 1 Billion dollars worth of new technological innovations per year through the further graduate development and increased creative output of over 5000 engineers within the U.S. engineering workforce. This unique concept has the potential to unlock America's competitive advantage for systems engineering innovation through the combined formidable strengths of U.S. industry and U.S. universities working in close alliance, thereby developing our domestic talent in engineering whereas neither can do the job alone.

\section{Conclusions and Path Forward - Investing in the Development of the U.S. Engineering Workforce for Innovation in Industry}

Sustaining our nation's engineering progress and competitive advantage for continuous full spectrum systems technological innovation in industry is vital to our economic growth and to our national security. To compete, America must innovate. And, every technology-based American company - who wants to compete - needs the core engineering competence and culture for innovation.

\subsection{Supporting a World Class U.S. Engineering Workforce for Innovation}

Now more than at any time in our recent history, we must invest in the continued growth and graduate development of America's engineers in industry - who are the nation's primary 'creative wellspring' and our core engineering capacity for systems innovation and our future technology. As such, the ASEE-National Collaborative Task Force on Engineering Graduate Education Reform recommends that this workforce initiative be fully funded and that the national demonstration project proceed in a timely manner.

The call for action for a new approach in the continued professional graduate education of the nation's engineers beyond 'pre-professional' baccalaureate education has been heard. Proven feasibility of the approach has been demonstrated in piecemeal fashion across the nation and in 
several competing nations. What needs to be done is to integrate the concept as a whole and to take it to the next level of excellence for this nation's competitive advantage. The concept is educationally sound and resources are at hand within each state across the nation to make this needed advancement happen.

\subsection{Unleashing America's Engineering Potential for Sustained Innovation in Industry}

The National Collaborative Task Force believes that what Vannevar Bush did in 1945 in conceiving of an effective system of research-based, graduate education that develops new scientific research and researchers simultaneously at the nation's universities, that we can do in the $21^{\text {st }}$ century in conceiving of an effective system of practice-centered, professional engineering graduate education that develops new innovative technology and engineering leaders simultaneously in the nation's industry.

The direct, tangible outcomes of generating new / improved / breakthrough technology for regional innovation across the United States, combined with the indirect outcomes of developing the 'innovative capacity' of engineers within regional industry as 'champions and leaders' for future systems innovation far exceed the initial educational investment. The National Collaborative initiative will serve as a pilot effort to ensure maximum opportunity for engineers within regional industry in the initial start-up states to continue their professional graduate engineering education - while fully employed in the region - for increasingly responsible leadership roles for innovation and also to set a national example for other states to follow. It is an initiative whose time is right for full-scale implementation to enhance U.S. innovation across the country. Implementing this transformation in U.S. engineering professional graduate education at this time is to ensure the continued development of the U.S. Engineering Workforce for systems innovation and its leadership for decades to come. 


\section{Bibliography}

1. National Academy of Engineering, Technically Speaking, 2002.

2. National Academy of Engineering, Educating the Engineer of 2020: Phase I Report, 2004.

3. National Academy of Engineering, Educating the Engineer of 2020: Phase II Report, 2005.

4. Committee on Science, Engineering, and Public Policy (COSEPUP), Reshaping the Graduate Education of Scientists and Engineers, National Academy Press, 1995.

5. Bush, V., Science: The Endless Frontier, 1945.

6. Council on Competitiveness, Picking Up the Pace, The Commercial Challenge to American Innovation, 1988.

7. UK Parnaby Report, 1992.

8. UK Engineering and Physical Sciences Research Council (EPSRC), Report of a Review of the EPSRC Engineering Doctorate Centres, March 2007.

9. Baldwin et al., NSF-Workshop on Continuing Education for Engineers at Mid-career, 1974.

10. Porter, M.E., On Competition, Harvard Business Series Press, 1998.

11. Gary F.W., A Business Look at Engineering Education, ASEE-Engineering Education, January 1986.

12. Council on Competitiveness, Innovate America, 2005.

13. Council on Competitiveness, http://www.compete.org, 2007.

14. ASEE, Green Report: Engineering Education for a Changing World, American Society for Engineering Education, 1994.

15. Kingston, Wm., Innovation: The Creative Impulse in Human Progress, John Calder, London, 1977.

16. Sherwin, C. W. and Isenson, R. S., Final Report: Project Hindsight, Director of Defense Engineering, Washington, July 1967.

17. Cetron, et al., Technical Resource Management, M.I.T. Press, 1969.

18. National Society of Professional Engineers, NSPE Levels of Engineering Responsibility, 2008.

19. American Society of Civil Engineers, ASCE Guidelines for Engineering Grades, 2008.

20. National Academies, Engineering Education and Practice in the United States: Foundations of Our TechnoEconomic Future, 1985.

21. National Academies, Rising Above the Gathering Storm: Energizing and Employing America for a Brighter Economic Future, National Academy Press, 2006. 


\section{Appendix A}

The Modern Paradigm of the Practice of Engineering for Creative Technology Development \& Innovation Responsive to Real-World Needs of Industry and Society

\section{Real Needs $\rightarrow$ Engineering $\rightarrow$ Useful Technology \\ $\downarrow \uparrow$}

Directed Basic Scientific Research to gain a better understanding of natural phenomena when needed or anticipated during the technology development project 


\section{Appendix B}

Demographics of Creative Potential of the U.S. Engineering Workforce for Technology Development \& Innovation Across the United States

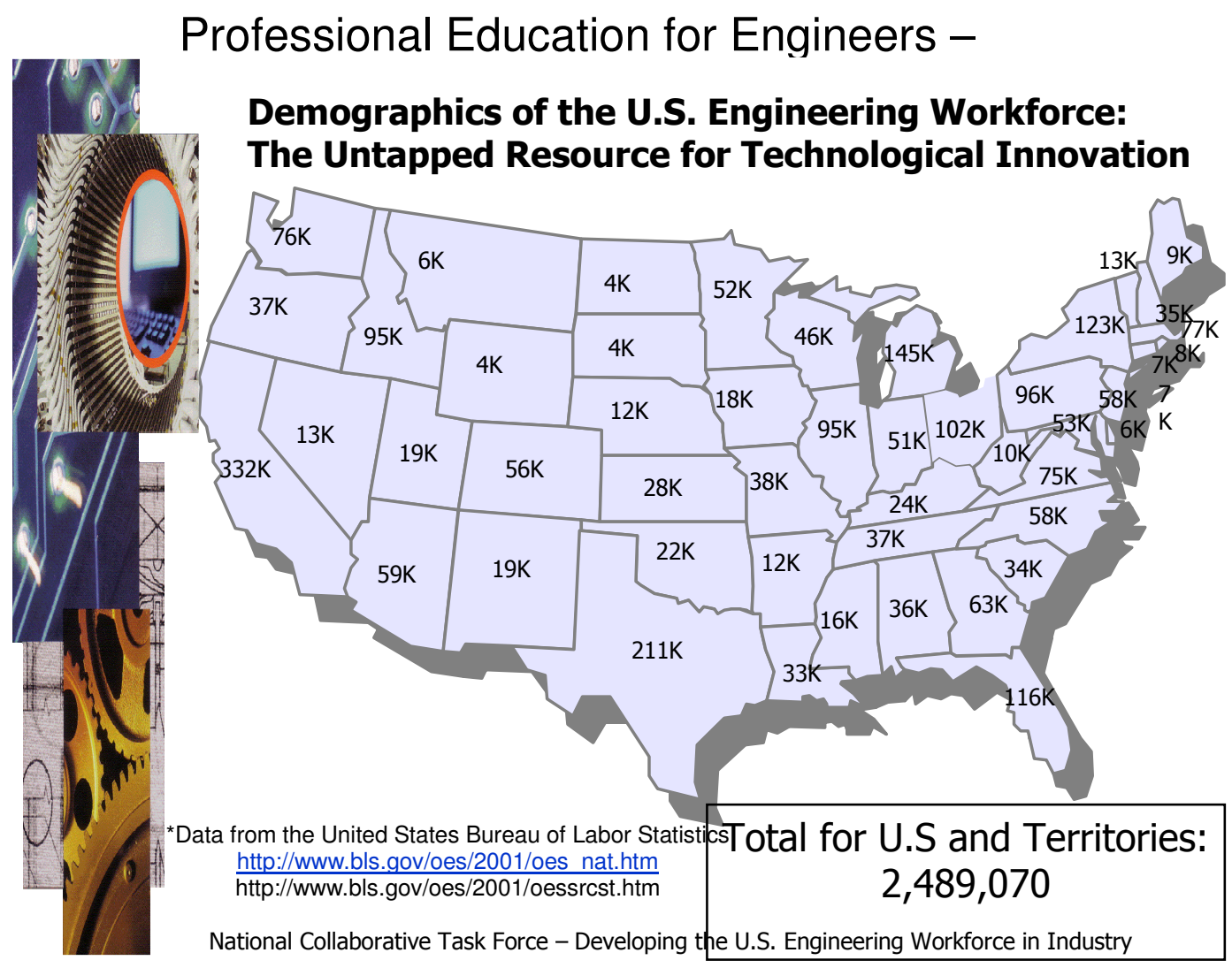




\section{Appendix C}

\section{Stages of Professional Growth and Responsibilities in the Practice of Engineering for Responsible Leadership of Technology Development \& Innovation}

\section{Stages of Growth \\ ENGINEER IX}

ENGINEER VIII

ENGINEER VII

ENGINEER VI

ENGINEER V

ENGINEER IV

ENGINEER III

ENGINEER I/II

(Entry Level Engineer)

\section{Typical Responsibilities-Autonomy-Judgment}

An engineer-leader at this level is in responsible charge of programs so extensive and complex as to require staff and resources of sizeable magnitude to meet the overall engineering objectives of the organization.

An engineer-leader at this level demonstrates a high degree of creativity, foresight, and mature judgment in planning, organizing, and guiding extensive engineering programs and activities of outstanding novelty and importance. Is responsible for deciding the kind and extent of engineering and related programs needed for accomplishing the objectives of the organization.

In a leadership capacity, is responsible for an important segment of the engineering program of an organization with extensive and diversified engineering requirements. The overall engineering program contains critical problems, the solutions of which require major technological advances and opens the way for extensive related development.

In a leadership capacity, plans, develops, coordinates, and directs a number of large and important projects or a project of major scope and importance. Or, as a senior engineer, conceives, plans, and conducts development in problem areas of considerable scope and complexity. The problems are difficult to define and unprecedented. This involves exploration of subject area, definition of scope, and selection of important problems for development.

In a leadership capacity, plans, develops, coordinates, and directs a large and important project or a number of small projects with many complex features. Or, as an individual principle engineer, carries out complex or novel assignments requiring the development of new or improved techniques and procedures. Work is expected to result in the development of new or refined equipment, materials, processes, or products. Technical judgment knowledge, and expertise for this level usually result from progressive experience.

Plans, schedules, conducts, or coordinates detailed phases of engineering work in part of a major project or in a total project of moderate scope. Fully competent engineer in all conventional aspects of the subject matter of the functional areas of assignments. Devises new approaches to problems encountered. Independently performs most assignments requiring technical judgment.

Performs work that involves conventional types of plans, investigations, or equipment with relatively few complex features for which there are precedents. Requires knowledge of principle and techniques commonly employed in the specific narrow areas of assignments.

Requires knowledge and application of known laws and data. Using prescribed methods, applies standard practices/techniques under direction of an experienced Engineer. 


\section{Appendix D - 1 \\ Benefits, Impact and Relevance of the Graduate Centers of Advanced Professional Engineering Graduate Education for Innovation To the Needs of the States and the Nation}

\section{Why the States and Nation Should Invest in the Engineering Workforce}

The new innovative 'Graduate Centers of Professional Engineering Education for Innovation' will have a major and beneficial effect in enhancing our nation's economic competitiveness and economic development of each participating state.

1) Enhances the nation's creative, innovative, and engineering leadership strengths for world-class technology development \& innovation through further professional education of the nation's engineers in industry, second to none.

2) Fuels economic development and new technology innovation, state-wide and nation-wide, by using federal, state, and industrial funding to create clusters of professionally-oriented graduate centers to develop industry's engineers within the regional U.S. engineering workforce for innovation across the country.

3) Enhances the innovative and teaching strengths of America's universities relevant to the creative practice of engineering in strong partnership with the practicing profession of engineering within America's industry.

4) Builds upon the combined and formidable teaching strengths in engineering from distinguished faculty in industry and from the universities.

5) Creates a viable solution and action plan to promote America's leadership in engineering though partnership with industry to develop the nation's engineers throughout their entire productive careers for innovative work in industry.

6) Enables wider opportunity for implementing high-quality professional graduate education for engineers across the country rather that limited to a few universities.

7) Strengthens America's core engineering competence in industry to innovate and compete

8) Strengthens existing, excellent university-industry relationships and creates new partnerships that enhance U.S. competitiveness

9) Creates a world-class model for 'lifelong learning' relevant to the needs of U.S. engineers

10) Builds a coherent sequence of professional education for the Master of Engineering, professional Doctor of Engineering, and professional Fellow of Engineering relevant to the progressive attributes required of engineers through all responsibility levels of engineering leadership within the profession 


\section{Appendix D - 2 \\ Benefits, Impact and Relevance of the Graduate Centers of Advanced Professional Engineering Graduate Education for Innovation To the Needs of National and Regional Universities}

\section{Why Universities Should Be Involved}

The new innovative 'Graduate Centers of Professional Engineering Education for Innovation' will have a major and beneficial effect in enhancing our nation's universities within their mission of professional education and enhancing economic development of each participating state.

1) It expands your institution's educational base along with multi-year funded support by various sponsors.

2) It expands the knowledge level of your faculty and connected industrial partners.

3) It places your institution at the frontier nationally of new engineering education concepts.

4) Your institution would be able to offer your students the best engineering education that is required in today's global society.

5) It promotes and encourages interaction with other peer group institutions.

6) It enhances and expands the institution's overall reputation as a leader in higher education in general.

7) It would aid in developing new industrial partnerships and fiscal support.

8) It positions your university to contribute to the economic development of your state and region.

9) It leverages the "Voice of the Customer" and provides a platform for innovation acceleration.

10) It provides a strong economic return on investment for industry.

11) It keeps your institution on pace with a changing business climate and global competition pressures within engineering. 


\section{Appendix D - 4 \\ Benefits, Impact and Relevance of the Graduate Centers of Advanced Professional Engineering Graduate Education for Innovation To the Needs of U.S. Industry}

\section{Why Industry Should Support this Initiative for Innovation}

The new innovative 'Graduate Centers of Professional Engineering Education for Innovation' will have a major and beneficial effect in enhancing the engineering innovative capacity of our nation's industry on a statewide basis across the country.

1) Develops new innovative technology, improvements, and breakthroughs in products, processes, systems, and operations directly relevant to underlying problems and specific needs of industry for near-term to long-term competitive advantage.

2) Strengthens American industry's 'innovative capacity' to compete and innovate by developing its core, creative and leadership talent in engineering.

3) Provides a cost-effective and viable engineering workforce development program for its core engineering talent by partnering with regional universities to deliver high-quality professional graduate education designed specifically for working professionals.

4) Enables coherent educational programs that further the positive growth of able engineers to reach responsible leadership positions as soon as qualified.

5) Enables core engineers and engineering leaders to attain high-quality professional graduate education without having to take time-out of the productive workforce or dislocating the family in the process.

6) Provides a viable opportunity and avenue for industry to partner with regional universities in shaping high-quality professional engineering graduate education on a long-term basis and sustaining partnership where both industry and the university are upgraded to the next level of excellence.

7) Enables industry's core engineers and engineering leaders to grow under mentoring relationships with distinguished faculty from industry and universities.

8) Provides a proven professional educational approach through practice-centered, projectbased learning at all levels of engineering responsibility that creates an excellent foundation and sustaining pipeline for providing U.S. industry with the leadership, technical and managerial skills needed for the future. 


\section{Appendix D - 5 \\ Benefits, Impact and Relevance of the Graduate Centers of Advanced Professional Engineering Graduate Education for Innovation to The Needs of U.S. Engineers and the Practicing Profession}

\section{Why the Nation's Engineers Should Engage in this Initiative}

The new innovative 'Graduate Centers of Professional Engineering Education for Innovation' will have a major and beneficial effect in enabling the further graduate development, 'lifelong learning' and positive growth of the nation's engineers across the country; and thereby upgrading the practicing profession as a whole in the United States for creative practice and meaningful engineering works of benefit to society in the spirit and intent of the mission of engineering.

1) Provides a clearly visible career path and educational opportunity at the professional graduate level for development of engineers as 'champions and leaders' relevant to the company's technological field for global competitiveness.

2) Enables each industry's engineers to interact within the wider engineering profession thereby exposing the engineer to a more global vision.

3) Provides engineers with experience, a leading edge practice-centered, professional education that enables their further growth and continued professional development throughout their entire productive careers of creative engineering practice in industry.

4) Enables sponsored engineers in industry to continue their professional education economically, without loss of income or up-rooting family in the process, through tuition reimbursement plans that are already in place in participating industry across the nation.

5) Provides engineers and engineering leaders with experience the rigorous opportunity for leading edge technology development \& innovation in an industrial context.

6) Develops competencies and engineering skill-sets that equip engineers for a range of leadership roles in industry.

7) Enables engineers to advance the 'state-of-the-art' of his or her technological field.

8) Enables the engineer to grow from novice to competent professional, to expert engineer, and to expert engineering leader in a very unique and effective approach to workforce development to enhance U.S. competitiveness. 


\section{Appendix E -1}

\section{National Collaborative Initiative for Advancement of Professional Engineering Graduate Education for the Nation's Engineers in Industry and Government Service}

Revitalizing the U.S. Engineering Workforce for Continuous

Technology Development \& Innovation in Industry

\section{Our Proposition is Straightforward}

The National Collaborative Task Force proposes that:

- In the innovation-driven economy, the U.S. engineering workforce is one of our nation's most valuable national resources for creating continuous technological developments and innovations in industry that strengthen our nation's innovative competitiveness for U.S. economic growth and national security

$\square \quad$ One of the best ways to strengthen U.S. innovation, competitiveness and America's economic growth for global leadership is on a regional basis across the country

> By improving our nation's system of professional engineering graduate education to support innovative engineering in America's industry

$>$ By clustering innovative graduate centers for professional education around regional industry in all regions and states of the nation that nurture the further creativity, innovative capacity, and leadership abilities of our nation's engineers as an innovation multiplier for competitiveness 


\section{Appendix E -2}

\section{National Collaborative Guidelines for Advancement of Professional Engineering Graduate Education for the Nation's Engineers in Industry and Government Service}

Revitalizing the

U.S. Engineering Workforce for Continuous

Technology Development \& Innovation in Industry

\section{Our Guidelines to Accomplish the Task are Attainable}

The National Collaborative Task Force Guidelines are:

> Focus on innovation and leadership and the development of the U.S. Engineering Workforce for innovative competitiveness in industry, second to none in the world

$>$ Vision -

"Innovation fosters the new ideas, technologies, and processes that lead to better jobs, higher wages and a higher standard of living. For advanced industrial nations no longer able to compete on cost, the capacity to innovate is the most critical element in sustaining competitiveness."

Council on Competitiveness

$>$ Workforce Development -

"The Council's business leaders agree that every company's most important asset are the people who walk in its doors every morning. Talented people creating new ideas and innovative technologies keep the economy strong, and growing stronger. The education and training that spark Americans' creativity and give them cutting-edge skills are a key to competitiveness.

Council on Competitiveness

$>$ Create a new, innovative professional curriculum combined with engineering practice that matches and supports the progressive core-competence skills required for effective engineering leadership of technology development \& innovation in industry - from beginning Entry Level Engineer through Chief Engineer Level for corporate technology responsibility

$>$ Create Graduate centers that will be "statewide clusters" for advanced professional education for engineering innovation and leadership in all 50 states across the nation

$>$ Use the combined formidable teaching and human resource strengths of regional universities and industry in this process in developing the capacity of the U.S. Engineering Workforce in industry for world-preeminence in technology development \& innovation 